\title{
Effect of flunarizine on memory function by using step down passive avoidance test in albino rats
}

\author{
Vinod Shinde*, Radha Yegnanarayan, Khyati Doshi, Akhil Agarwal
}

Department of Pharmacology, Smt. Kashibai Navale Medical College and General Hospital, Narhe, Pune, Maharashtra, India

Received: 17 November 2016 Accepted: 29 November 2016

*Correspondence to:

Dr. Vinod Shinde,

Email: vshinde62@gmail.com

Copyright: (C) the author(s), publisher and licensee Medip Academy. This is an openaccess article distributed under the terms of the Creative Commons Attribution NonCommercial License, which permits unrestricted noncommercial use, distribution, and reproduction in any medium, provided the original work is properly cited.

\begin{abstract}
Background: Aim of the study was to evaluate effect of flunarizine on memory function by using step down passive avoidance test in albino rats.

Methods: The study approved by IAEC was conducted using 24 albino rats ( $\mathrm{n}=$ 6 in each group). Effect of normal saline $(0.1 \mathrm{ml} / 100 \mathrm{~g})$, fluoxetine $(10 \mathrm{mg} / \mathrm{kg}$, intraperitoneally (ip)), and flunarizine ( 2 and $10 \mathrm{mg} / \mathrm{kg}$, ip) on memory retrieval in rats was evaluated by using Step-down passive avoidance test. One day prior to conducting the test, each rat was trained to stay on central shock free zone platform (SFZ) for at least 90s. For the training, animals were applied shock of 15 s every time when the rat stepped down placing all the paws on the grid floor. On the consecutive day retention of the memory was tested thirty minutes after administration of all test drugs. Step down latency (SDL) and number of mistakes was observed for a period of $5 \mathrm{~min}$ in all rats.

Results: The data was analyzed by one-way analysis of variance (ANOVA) and Student's t-test and $\mathrm{P}<0.05$ was considered significant. Mean Step down latency was significantly increased in fluoxetine $(10 \mathrm{mg} / \mathrm{kg}$, i.p) group as compared to the normal saline $(\mathrm{P}<0.05)$. SDL was increased in flunarizine $(10 \mathrm{mg} / \mathrm{kg}$, i.p) group but it was not statistically significant $(\mathrm{p}>0.05)$. Number of mistakes was reduced in both fluoxetine and flunarizine $(10 \mathrm{mg} / \mathrm{kg}$, i.p) group and was statistically significant when compared to vehicle treated group.
\end{abstract}

Conclusions: The results of the present study indicate beneficial effects of flunarizine in memory retrieval in albino rats.

Keywords: Flunarizine, Fluoxetine, Memory, Step down avoidance test

\section{INTRODUCTION}

With the advancement of science, the life expectancy of man has increased and so are the problems associated with longevity. Aging is a major risk factor for various neurological disorders involving neurodegeneration such as Alzheimer disease, Parkinson's disease and dementia. $^{1,2}$ In aged conditions, many physical, biological, chemical, neurophysiological and neuropathological changes occur due to loss in synaptic plasticity, synaptic dysfunction, which further leads to subsequent triggering of neurodegenerative processes. ${ }^{3}$ The growing need for the treatment of cognitive impairment due to aging or dementia has led to the search for potential cognition enhancing drugs. The various compounds presently under development represent an alternative to cholino-mimetic therapy and include new chemical entities as well as piracetam and its newer analogs. Antiinflammatory agents, antioxidants, nonsteroids and some neuroprotective agents have also been used, but with limited success. ${ }^{4}$

The recognition of calcium channel antagonists (CCAs) binding sites in the hippocampal neuronal cells of the brain has raised the hope that these drugs might also be useful in modulating memory function. ${ }^{5}$ Calcium channel blockers have also been used to treat memory loss. ${ }^{6}$ Dihydropyridine CCAs (DHP-CCAs) like nimodipine, nifedipine, nicardipine, and felodipine have been reported to have significant nootropic activity. Nimodipine, for instance, can ameliorate age-related impairments of memory acquisition and retention; and the amnestic effects of cerebral hypoxia can be reverted by nicardipine, felodipine, and nifedipine. ${ }^{7,8}$ This nootropic effect has been observed in humans too and is generally 
interpreted as a compensatory action over age-altered calcium metabolism.

The calcium channel blocker flunarizine is a lipophilic diphenyl piperazine derivative; it is a relatively weak calcium channel blocker that also inhibits $\mathrm{Na}+$ channels. ${ }^{11}$ Flunarizine has the ability to cross the blood brain barrier (BBB), antagonize calcium influx, and to interfere with the neurotransmitter system. ${ }^{12}$ Due to its higher liphophilicity and better blood brain barrier penetrability, flunarizine might have beneficial effects on memory function similar to other calcium channel antagonists, which could be useful in treating various memory disorders. However, little investigation has been made, of the effects of flunarizine on memory function. Therefore, the present study was designed to evaluate the effect of flunarizine on memory function by using step down passive avoidance test in albino rats.

Step-down Passive avoidance test is one of the most common animal tests in memory research. It is based on the principle that rodents (mouse or rat) in an open field spend most of the time close to the walls and in the corners. When placed on an elevated platform in the center of a rectangular compartment, it steps down almost immediately to the floor to explore the enclosure and to approach the wall. The technique is employed in different modifications described by various researchers. Stepdown passive avoidance test is simple, inexpensive, and reliable for screening of drugs affecting memory function in rodents. ${ }^{13}$

\section{METHODS}

\section{Animals}

All the pharmacological experiments were conducted using albino rats $(n=6)$, weighing between 200 and 250 $\mathrm{g}$ (11 months old). The animals were maintained under controlled environmental conditions such as temperature $\left(21 \pm 2^{\circ} \mathrm{C}\right)$, relative humidity $(30-70 \%)$, and photoperiod of $12 / 12 \mathrm{~h}$ period. They were provided with standard commercial pelleted diet and Aquaguard drinking water ad libitum. They were acclimatized for at least 7 days before the start of experiments. The care and use of laboratory animals were strictly in accordance with the guidelines prescribed by the Institutional Animal Ethics Committee constituted under the guidelines of Committee for the Purpose of Control and Supervision of Experiments on Animals (CPCSEA, India).

\section{Drugs}

The following drugs were used: flunarizine, fluoxetine, and normal saline. Fluoxetine was used as the positive control to compare the results of flunarizine. Flunarizine and fluoxetine were dissolved in sterile normal saline. Freshly prepared drug solutions were injected ip, $30 \mathrm{~min}$ prior to the testing, in the volume of $0.1 \mathrm{ml} / 100 \mathrm{~g}$ body weight. Concurrent control group animals received appropriate volume of normal saline ip.

\section{Experimental design}

Twenty-four naïve albino rats were used for this study, and they were divided into four groups $(n=6)$. First group considered as control and received normal saline $(0.1$ $\mathrm{ml} / 100 \mathrm{~g}$, ip). Second group received fluoxetine (10 $\mathrm{mg} / \mathrm{kg}$, ip), and served as positive control. ${ }^{14,15}$ Third and fourth groups were treated with two different doses of flunarizine ( 2 and $10 \mathrm{mg} / \mathrm{kg}$, ip). From the two doses of flunarizine, first dose $2 \mathrm{mg} / \mathrm{kg}$ obtained by extrapolating human dose for rats, second dose, that is, $10 \mathrm{mg} / \mathrm{kg}$ in rats was used, because in our previous study we obtained significant antidepressant effect of flunarizine in rats at this dose. ${ }^{16,17}$ The study was approved by Institutional Review Board and Institutional Animal Ethics Committee (Protocol number: 16:01, dated 10/04/2014).

\section{Step down avoidance paradigm in rat}

Step down behaviour was employed to examine memory loss by the procedure as described by Vignisse et al, with slight modifications. ${ }^{18}$ The apparatus used consisted of an acrylic box $(30 \times 30 \times 45 \mathrm{~cm})$ with a stainless steel grid floor, having a shock free zone (SFZ) (central platform) on the center of the grid floor. The grid floor was connected to a shock device which delivers foot shocks (20 V AC). One day prior to conducting the test, each rat was individually trained to stay on the central SFZ for at least $90 \mathrm{~s}$; for this the animals were applied shock for $15 \mathrm{~s}$ every time when the rat stepped down placing all paws on the grid floor. The process was repeated until the animal learned to stay on the central SFZ for at least $90 \mathrm{~s}$. Retention of memory was tested on the consecutive days by administrating treatment $30 \mathrm{~min}$ before the test. After the drug administration, each rat was again individually placed on the central SFZ, and then step down latency (SDL) and number of mistakes was observed for $5 \mathrm{~min}$. A significantly increased SDL and the decreased number of mistakes compared to the vehicle control are the indices of protective effect on the retrieval of memory. ${ }^{19}$

\section{Statistical analysis}

All values are expressed as mean \pm SEM from 6 animals. Behavioural data were analyzed using one-way ANOVA and Student's t-test. $\mathrm{P}$ values $<0.05$ were considered as statistically significant. Statistical analysis was done by using the PRIMER statistical software package.

\section{RESULTS}

Mean Step down latency was significantly increased in fluoxetine (10 mg/kg, i.p) group as compared to the normal saline group $(\mathrm{P}<0.05)$. SDL was increased in flunarizine $(10 \mathrm{mg} / \mathrm{kg}$, i.p) group but it was not statistically significant $(\mathrm{P}>0.05)$. Number of mistakes was reduced in both fluoxetine and flunarizine $(10 \mathrm{mg} / \mathrm{kg}$, 
i.p) groups and was statistically significant when compared to vehicle treated group (Table 1).

Table 1: Effects of Flunarizine on Step-down latency and number of mistakes in Step-down passive avoidance test in rats.

\begin{tabular}{|lll|}
\hline Treatment groups & $\begin{array}{l}\text { Step-down latency } \\
\text { (in seconds) }\end{array}$ & $\begin{array}{l}\text { Number of } \\
\text { mistakes }\end{array}$ \\
\hline $\begin{array}{l}\text { Normal saline } \\
(0.1 \mathrm{ml} / 100 \mathrm{gm}, \mathrm{i} . \mathrm{p})\end{array}$ & $21.83 \pm 2.61$ & $8.5 \pm 1.09$ \\
\hline $\begin{array}{l}\text { Fluoxetine (Positive } \\
\text { control) } \\
(10 \mathrm{mg} / \mathrm{kg}, \text { i.p. })\end{array}$ & $88.5 \pm 29.29^{*}$ & $\begin{array}{l}2.17 \pm \\
0.48^{*}\end{array}$ \\
\hline $\begin{array}{l}\text { Flunarizine } \\
(2 \mathrm{mg} / \mathrm{kg}, \text { i.p) }\end{array}$ & $24.0 \pm 4.09^{\mathrm{ns}}$ & $7.67 \pm$ \\
\hline $\begin{array}{l}\text { Flunarizine } \\
(10 \mathrm{mg} / \mathrm{kg}, \mathrm{i} . \mathrm{p})\end{array}$ & $33 \pm 9.87^{\mathrm{ns}}$ & $\begin{array}{l}\mathrm{ns} \\
4.33 \pm\end{array}$ \\
\hline
\end{tabular}

Results are expressed as mean \pm SEM obtained from 6 animals. ns: statistically nonsignifcant; *P $<0.05$; vs normal control

\section{DISCUSSION}

The present work investigated the effect of flunarizine, a calcium channel blocker, on memory function in stepdown passive avoidance test in rats. The result of the present work provided evidence that mean step-down latency was increased in fluoxetine and flunarizine $(10 \mathrm{mg} / \mathrm{kg}$, ip) groups as compared to the normal saline group. The increase in step-down latency with fluoxetine was statistically significant compared with normal saline. Though there was an increase in step-down latency in flunarizine $(10 \mathrm{mg} / \mathrm{kg}$, ip) group, it was not found to be statistically significant when compared to normal saline group. Also, the numbers of mistakes were significantly reduced in both fluoxetine and flunarizine $(10 \mathrm{mg} / \mathrm{kg}$, ip) groups when compared with vehicle treated group. The results of present study showed an increase in step-down latency and significant reduction in number of mistakes in passive avoidance test by flunarizine at a dose of 10 $\mathrm{mg} / \mathrm{kg}$ in rats, which support its possible use as a memory enhancer.

In the present study, $2 \mathrm{mg} / \mathrm{kg}$ dose of flunarizine in rats was extrapolated from currently used doses of flunarizine, for prophylactic treatment of migraine in humans. At this dose we did not observe any beneficial effect on memory retrieval in rats. This suggests that, flunarizine may not have any effect on memory function at presently used human dose and might need higher or more frequent doses to be effective.

The precise mechanisms by which flunarizine produced beneficial effects on memory retrieval in rodents is not completely understood. Intraneuronal $\mathrm{Ca} 2+$ regulation is critical for many neuronal processes, including synaptic plasticity, and for the macroscopic processes based on them, including learning and memory formation. Under normal physiological conditions, cytosolic $\mathrm{Ca} 2+$ levels are tightly regulated by a multitude of proteins, but during normal aging and dementia, intracellular $\mathrm{Ca} 2+$ becomes dysregulated. ${ }^{20,21}$ This dysregulation in $\mathrm{Ca}^{+}$ levels is associated with impairments in learning and memory. ${ }^{22-24}$ Also, in patients with Alzheimer's disease (AD), cytosolic $\mathrm{Ca} 2+$ levels and influx via L-type Ca2+channels are increased. ${ }^{25,26}$ Researchers have used Ca2+channel blockers, such as nimodipine and nitrendipine, in treatment of memory deficits in dementia. ${ }^{27,28}$

Increase in intracellular $\mathrm{Ca} 2+$ levels in hippocampal neuronal cells may impair learning and memory through increases in calcium-dependent post-burst afterhyperpolarizations (AHPs). ${ }^{29}$ Specifically, slow AHPs (sAHPs) are increased by an increase in cytosolic $\mathrm{Ca} 2+$. Increases in the amplitude and duration of sAHPs result in decreases in intrinsic neuronal excitability, which is associated with impairment in learning and memory. ${ }^{30}$

Flunarizine is a non-selective voltage dependent calcium channel blocker. It blocks not only the resting state but, more preferentially, the inactivated state of both the Land T-type $\mathrm{Ca} 2+$ channels. $^{31}$ Voltage sensitive L-type $\mathrm{Ca} 2+-$ channels appear to be particularly important both for modulating AHPs and for modulating memory. ${ }^{32}$ These evidences suggest that flunarizine, might also modulate AHPs in hippocampal neuronal cells and enhance memory retrieval in rats by its blocking action on resting and inactivated $\mathrm{L}$ type $\mathrm{Ca} 2+$ channels. In another study, David Quartermain et al. showed that amlodipine can facilitate memory consolidation and retrieval in dose dependent manner $(5,7,9,15$ and 30 $\mathrm{mg} / \mathrm{kg}){ }^{33}$ In present study also, flunarizine showed dose dependent increase in step-down latency and reduction in number of mistakes in passive avoidance test in rats, which suggest that slightly higher doses of flunarizine may produce significant increase in step-down latency and memory retrieval in rats. These findings are also consistent with numerous other studies demonstrating that memory is enhanced by calcium antagonists. ${ }^{7,34-36}$

Notable advantage of flunarizine is its cost, which is 1020 times lower in comparison with other cognition enhancers. However, detailed animal and radioligand studies are required to establish the efficacy of flunarizine at molecular level especially in aged animals, so that the data will be strong enough to consider this drug for some clinical trials and to facilitate the therapeutic repositioning of this drug in near future for a variety of cognitive disorders.

\section{CONCLUSION}

The results of the present study indicate beneficial effects of flunarizine on memory retrieval in albino rats.

\section{ACKNOWLEDGMENT}

The help rendered by Dr. Prachi Pophale, Veterinary officer, SKNMC and GH-Pune, is duly acknowledged. 
Funding: No funding sources

Conflict of interest: None declared

Ethical approval: The study was approved by the Institutional Ethics Committee

\section{REFERENCES}

1. Heikkinen R, Malm T, Heikkila J, Muona A, Tanila $\mathrm{H}$, Koistinaho M, et al. Susceptibility to focal and global brain ischemia of Alzheimer mice displaying abeta deposits: effect of immunoglobulin. Aging Dis. 2014;5(2):76-87.

2. Mandel SA, Youdim MB. In the rush for green gold: can green tea delay age-progressive brain neurodegeneration? Recent Pat CNS Drug Discov. 2012;7(3):205-17.

3. Ando S. Neuronal dysfunction with aging and its amelioration. Proc Jpn Acad Ser B Phys Biol Sci. 2012;88(6):266-82.

4. Prasad KN, William CC, Prasad KC. Risk factors for Alzheimer's disease: Role of multiple antioxidants, non-steroidal anti-inflammatory and cholinergic agents alone or in combination in prevention and treatment. J Am Coll Nutr. 2002;21(6):506-22.

5. Moschovos C, Papatheodoropoulos C. The L-type voltage-dependent calcium channel long-term potentiation is higher in the dorsal compared with the ventral associational/commissural CA3 hippocampal synapses. Neurosci Res. 2015 Nov 2. pii: S0168$0102(15) 00259-X$

6. Brooks SP, Croft AP, Norman G, Shaw SG, Little HJ. Nimodipine prior to alcohol withdrawal prevents memory deficits during the abstinence phase. Neuroscience. 2008;157(2):376-84.

7. Deyo RA, Straube KT, Disterhoft JF. Nimodipine facilitates associative learning in aging rabbits. Science. 1989;243(4893):809-11.

8. Zupan G, Mrsic J, Simonic A. Effects of nicardipine, felodipine and nifedipine on passive avoidance behavior of intact and hypoxia-exposed rats. Arch Int Pharmacodyn Ther. 1993;325:61-9.

9. Ban TA, Morey L, Aguglia E, Azzarelli O, Balsano F, Marigliano V, et al. Nimodipine in the treatment of old age dementias. Prog Neuropsychopharmacol Biol Psychiatry. 1990;14(4):525-51.

10. Gibson GE, Peterson C. Calcium and the aging nervous system. Neurobiol Aging. 1987;8(4):329-43.

11. Tripathi KD. 5-Hydroxytryptamine, its Antagonists and Drug Therapy of Migraine, In: Tripathi KD, editor. Essentials of Medical Pharmacology, $7^{\text {th }}$ ed. New Delhi: Jaypee Brothers; 2013:180.

12. Agarwal VK, Jain S, Vaswani M, Padma MV, Maheshwari MC. Flunarizine as add-on therapy in refractory epilepsy: A open trial. J Epilepsy. 1996;9(1):20-2.

13. Huwiler A. Inhibitory (passive) avoidance test. In: Vogel HG, editor. Drug Discovery and Evaluation: Pharmacological Assays. $3^{\text {rd }}$ ed, Vol. 1. SpringerVerlag: Berlin, New York; 2008:619-20.
14. Jafary L, Reisi P, Naghsh N. Effects of fluoxetine on memory under forced treadmill exercise conditions in male rats. Adv Biomed Res. 2015;4:235.

15. Stagni F, Giacomini A, Guidi S, Ciani E, Ragazzi E, Filonzi $\mathrm{M}$ et al. Long-term effects of neonatal treatment with fluoxetine on cognitive performance in Ts65Dn mice. Neurobiol Dis. 2015;74;204-18.

16. Guidance for Industry, Estimating the Maximum Safe Starting Dose in Initial Clinical Trials for Therapeutics in Adult Healthy Volunteers. U. S. Dept of Health and Human Services, Food and Drug Administration and Center for Drug Evaluation and Research 2005. (Accessed August 5, 2015, at http://www.fda.gov/cder/guidence/index.htm).

17. Shinde V, Yegnanarayan R, Shah P, Gupta A, Pophale P. Antidepressant-like activity of flunarizine in modified tail suspension test in rats. N Am J Med Sci. 2015;7(3):100-3.

18. Vignisse J, Steinbusch HW, Grigoriev V, Bolkunov A, Proshin A, Bettendorff L, et al. Concomitant manipulation of murine NMDA- and AMPAreceptors to produce pro-cognitive drug effects in mice. Eur Neuropsychopharmacol. 2014;24(2):30920.

19. Khurana N, Ishar MP, Gajbhiye A, Goel RK. PASS assisted prediction and pharmacological evaluation of novel nicotinic analogs for nootropic activity in mice. Eur J Pharmacol. 2011;662(1-3):22-30.

20. Foster TC, Kumar A. Calcium dysregulation in the aging brain. Neuroscientist. 2002;8(4):297-301 .

21. Thibault O, Gant JC, Landfield PW. Expansion of the calcium hypothesis of brain aging and Alzheimer's disease: minding the store. Aging Cell. 2007;6(3):307-17.

22. Thibault O, Hadley R, Landfield PW. Elevated postsynaptic $[\mathrm{Ca} 2+] \mathrm{i}$ and L-type calcium channel activity in aged hippocampal neurons: relationship to impaired synaptic plasticity. J Neurosci. 2001;21(24):9744-56.

23. Miyashita T, Kubik S, Lewandowski G, Guzowski JF. Networks of neurons, networks of genes: an integrated view of memory consolidation. Neurobiol Learn Mem. 2008;89(3):269-84.

24. Berridge MJ. Calcium signalling and Alzheimer's disease. Neurochem Res. 2011;36(7):1149-56.

25. Mattson MP, Cheng B, Davis D, Bryant K, Lieberburg I, Rydel RE. Beta-Amyloid peptides destabilize calcium homeostasis and render human cortical neurons vulnerable to excitotoxicity. J Neurosci. 1992;12(2):376-89.

26. Thibault O, Landfield PW. Increase in single L-type calcium channels in hippocampal neurons during aging. Science. 1996;272(5264):1017-20.

27. Forette F, Seux ML, Staessen JA, Thijs L, Babarskiene MR, Babeanu S, et al. The prevention of dementia with antihypertensive treatment: new evidence from the Systolic Hypertension in Europe (Syst-Eur) study. Arch Intern Med. 2002;162(18):2046-52. 
28. López-Arrieta JM, Birks J. Nimodipine for primary degenerative, mixed and vascular dementia. Cochrane Database Syst Rev. 2002;3:CD000147.

29. McAfee DA, Yarowksy PJ. Calcium-dependent potentials in the mammalian sympathetic neurone. J Physiol. 1979;290(2):507-23.

30. Andrade R, Foehring RC, Tzingounis AV. The calcium-activated slow AHP: cutting through the Gordian knot. Front Cell Neurosci. 2012;6:47.

31. Kuga T, Sadoshima J, Tomoike H, Kanaide H, Akaike N, Nakamura M. Actions of $\mathrm{Ca} 2+$ antagonists on two types of $\mathrm{Ca} 2+$ channels in rat aorta smooth muscle cells in primary culture. Circ Res. 1990;67(2):469-80.

32. Thompson LT, Moyer JR, Black J, Disterhoft JF. Cellular mechanisms for nimodipine's reduction of aging-related learning deficits. Adv Behav Biol. 1992;40:241-56.

33. Quartermain D, Hawxhurst A, Ermita B, Puente J. Effect of the calcium channel blocker amlodipine on memory in mice. Behav Neural Biol. 1993;60(3):211- 9.

34. Wilmott LA, Thompson LT. Sex- and dosedependent effects of post-trial calcium channel blockade by magnesium chloride on memory for inhibitory avoidance conditioning. Behav Brain Res. 2013;257:49-53.

35. Quartermain D, deSoria VG, Kwan A. Calcium channel antagonists enhance retention of passive avoidance and maze learning in mice. Neurobiol Learn Mem. 2001;75(1):77-90.

36. Schafe GE. Rethinking the role of L-type voltagegated calcium channels in fear memory extinction. Learn Mem. 2008;15(5):324-5.

Cite this article as: Shinde V, Yegnanarayan R, Doshi K, Agarwal A. Effect of flunarizine on memory function by using step down passive avoidance test in albino rats. Int $\mathrm{J}$ Basic Clin Pharmacol 2017;6:30-4. 